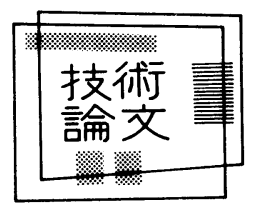

\title{
動的外力と船尾管軸受特性を考慮した 軸系アライメント*
}

\section{斎 藤 年 正 $^{* *}$}

\author{
Dynamic Alignment Taking Account of Propeller Forces \\ and Stern Tube Bearing Performances
}

By Toshimasa Saitoh

The recent growth in propulsive power of ships has resulted in cases of severe damage to the stern tube bearings and the sealing rings. In most cases, the shaft alignment analysis has been still only carried out under non-operating condition. This static alignment condition is considerably effected by some external factors, such as propeller forces and moments, double bottom deformations, bearing flexibility and thermal influence.

The paper discusses the theroretical and experimental study of the dynamic shaft alignment in service loading of stern tube bearings. The distortion and bowing of the tail shaft under the influence of the propeller forces and moments is taken into account of the analysis of the stern tube bearing performances.

\section{1. 緒言}

従来の船用推進軸系の設計は, 強度計算を主体として 実施されてきたが, 最近では軸系の各種振動, 軸の静的 ・動的アライメント，および軸受性能を含む総合的な考 え方から設計を行おうという傾向が現われている ${ }^{1)}$ ：乙 のような傾向は既に大形タンカーが出現した当時, 舶用 船尾管軸受の性能について行われた, 軸受の片あたり特 性の検討にその端緒が見い出される゙2. 以降船尾管軸受 特性を考虑に入れた軸系アライメント計算法 ${ }^{3)}$ が考えら れ，従来のアライメント計算法に代わる，より実効的な 計算手法が展開され今日に至っている.

上記計算手法が開発された当初は, 主として大形船や, 高速高出力船のように軸受荷重が大きく，軸受の片あた り傾向の著しい船舶や，プロペラ水力作用の大きな船舶 に対して，上記アライメント計算が適用されていたよう に見受けられる.しかし，現在ではそのような限定され た考えはなくなっており，より多面的な検討が行われつ つある。

舶用船尾管軸受は $L / D$ が大き，かつ重量の大きなプ ロペラを片持状に支持するために，軸受の片あたりが発 生し易い状況にある.また負荷の上昇に伴い，プロペラ の水力作用による影響が大きくなるために，軸は軸受内

\footnotetext{
*原稿受付 昭和 57 年 10 月 15 日

昭和 57 年秋季学術講演(昭和 57 年 10 月 27 日)

**正会員 日立造船 (株) 技術研究所(堺市築港新町 1-5)
}

で無視できない大きさのたわみを有するようになる，軸 のたわみを考慮に入れた船尾管軸受の特性解析によれ ば4), 軸のたわみの有無により, 軸受特性值はかなり変 化することが知られている. 他方, プロペラの水力作用 によるプロペラ・フォースならびに曲げモーメンドは) プロペラの特性と伴流分布形状によってその大きさが決 まり，軸系の動的アライメントに対して大きな影響をお よぼす. しかし, 伴流分布形状と動的アライメントの関 係については，まだ十分に明らかにされているとはいえ ない.

本報では，軸のたわみを考虑に入れた軸受特性と，伴 流分布から求められるプロペラ・フォースならびに曲げ モーメントを, 動的アライメント計算に取入れた解析法 を示し，さらに，実船に適用した場合について検討する.

\section{2. 解析の概要}

2.1 アライメント計算 図1亿示すように, 座 標系は軸系の船尾端を原点とし， $x$ 軸を軸心方向船首向 き, $y$ 軸を水平左舷方向, $z$ 軸を鉛直上方向とする.

図 2 に示すように, 軸を任意の断面で分割し, 分割区 間内の軸を質量のない弾性梁(曲げ剛性を $E I(E$ : 䋛弾性 係数, $I$ : 断面二次モーメント), 女ん断剛性を $G A(G$ : 横弹性係数， $A$ : 断面積), 長さを $l$ とする)，集中質量 $m$, 等価軸受ばね定数 $k$ の各要素からなる基本要素に置 換し, 軸系の各状態量を伝達マトリクス法を用いて解く. $u, v$ を $y, z$ 軸方向のたわみ, $\phi, \varphi$ を $y, z$ 軸回りのた 


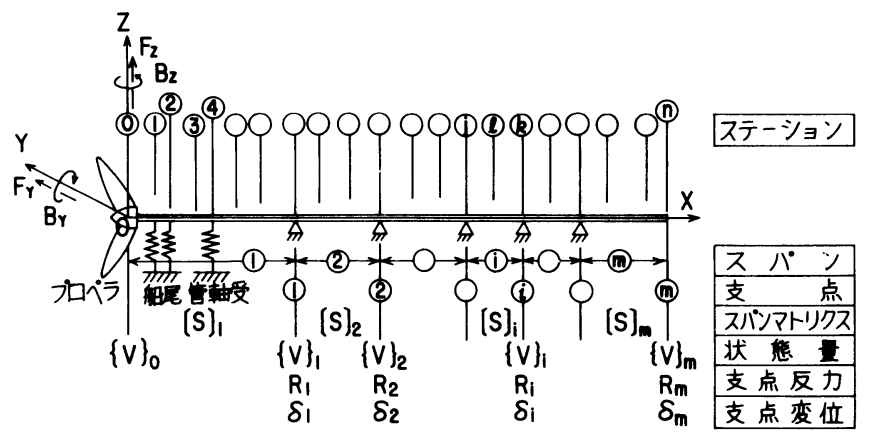

困 1 座標系ならびに軸系分割要領

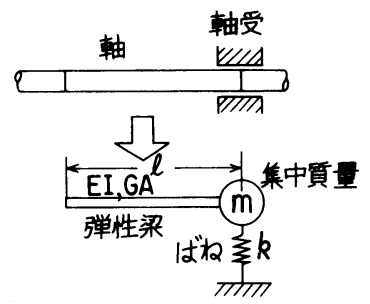

図 2 基本要素モデル

わみ角, $M_{y}, M_{z}$ を $y, z$ 軸回りの曲げモーメント， $V_{y}$, $V_{z}$ を $y, z$ 軸方向のせん断力とし，任意分割点(ステーシ ョンと呼ぶ） $i$ の状態量 $\{z\}_{i}$ を式(1)で定義する.

$\{z\}_{i}=\left\{u, \varphi, M_{z},-V_{y},-v, \phi, M_{y}, V_{z}, 1\right\}_{i}^{\mathrm{T}}$ (1)

1 は強制項， \{ $\}^{\mathrm{T}}$ は転置行列を表わす。たわみ，女 ん断力, 外力の正の方向は座標軸の正の方向とし, たわ み角, 曲げモーメント, 外曲げモーメントは, 座標軸の 正の方向に向かって右ねじの進む向きを正とする.

困 1 亿示したように, $n$ 個の基本要素に分割された軸 系の, 隣接ステーションには式 (2) の関係が成立する.

$$
\{z\}_{i}=[\mathrm{T}]_{i}\{z\}_{i-1}
$$

$[\mathrm{T}]_{i}$ は図 2 に示した基本要素の伝達マトリクスを表 わし，式(3)で表わされる.

$[\mathrm{T}]_{i}$

\begin{tabular}{||c|c|c|c|c|c|c|c|c||}
\hline 1 & $l$ & $\beta$ & $r$ & 0 & 0 & 0 & 0 & 0 \\
\hline 0 & 1 & $\alpha$ & $\beta$ & 0 & 0 & 0 & 0 & 0 \\
\hline 0 & $k_{z \varphi}$ & $1+\alpha k_{z \varphi}$ & $l+\beta k_{z \varphi}$ & 0 & $k_{z \varphi}$ & $\alpha k_{z \varphi}$ & $\beta k_{z \varphi}$ & $-B_{z}$ \\
\hline$-k_{y y}$ & $-l k_{y y}$ & $-\beta k_{y y}$ & $1-r k_{y y}$ & $k_{y z}$ & $l k_{y z}$ & $\beta k_{z z}$ & $r k_{y z}$ & $F_{y}$ \\
\hline 0 & 0 & 0 & 0 & 1 & $l$ & $\beta$ & $r$ & 0 \\
\hline 0 & 0 & 0 & 0 & 0 & 1 & $\alpha$ & $\beta$ & 0 \\
\hline 0 & $k_{y \varphi}$ & $\alpha k_{y \varphi}$ & $\beta k_{y \varphi}$ & 0 & $k_{y \varphi}$ & $1+\alpha k_{y \varphi}$ & $1+\beta k_{y \varphi}$ & $-B_{y}$ \\
\hline$k_{z y}$ & $l k_{z y}$ & $\beta k_{z y}$ & $r k_{z y}$ & $-k_{z z}$ & $-l k_{z z}$ & $-\beta k_{z z}$ & $1-r k_{z z}$ & $-F_{z}+m g$ \\
\hline 0 & 0 & 0 & 0 & 0 & 0 & 0 & 0 & 1 \\
\hline
\end{tabular}

ととに,

$$
\alpha=l / E I, \quad \beta=l^{2} / 2 E I, \quad \gamma=l^{3} / 6 E I-\kappa l / A G
$$

であり， $F_{y}, F_{z}$ は $y, z$ 軸方向に作用する外力， $B_{y}, B_{z}$ は $y, z$ 軸回りに作用する外曲げモーメント， $\kappa$ はせん断
係数, $g$ は重力加速度を表わす.

式(3)は $y, z$ 軸方向について, 軸受部の連 成ばねが作用する場合の伝達マトリクスであ るが，以下においては，連成作用がない場合 を取扱う. このとき式 (3)の $(9 \times 9)$ 次の伝 達マトリクスは, $y, z$ の各座標軸について, $(5 \times 5)$ 次の伝達マトリクス要素で形成され る.

軸系を単純支持点 (船尾管軸受以外の軸受 は単純支持として取扱う)で分割し，ての分 割区間をスパンと定義する. 各スパン内に含 まれる基本要素伝達マトリクス $[\mathrm{T}]_{i}$ を，船 尾側から順次乗じて得られるマトリクスをスパン・マト リクスと呼び,〔S〕で表わす。すすなわち,

$$
[\mathrm{S}]_{i}=[\mathrm{T}]_{k}[\mathrm{~T}]_{k^{-1}} \cdots[\mathrm{T}]_{j+2}[\mathrm{~T}]_{j+1}
$$

$\{V\}_{i}$ を軸端あるいは支点 $i$ の状態量, $\{V\}_{i}^{\mathrm{R}},\{V\}_{i}^{\mathrm{L}}$ 支点 $i$ の右側 $(\mathrm{R})$, 左側 ( $\mathrm{L}$ )の状態量, $R_{i}$ を未知支点反 力, $\delta_{i}$ を既知支点変位 (オフセット量, 油膜厚さ, 二重 底の変形なじを含む), $m$ をスパン総数, $n$ を総基本要 素数とする. 状態量計算は $y, z$ 軸方向についてそれぞれ 個別に実行する.

スパン・マトリックス $[\mathrm{S}]_{i}$ の要素 $\left\{S_{i, j, k}\right\}(i=1, \cdots$ $m, \quad j=1, \cdots 5, \quad k=1, \cdots 5)$ を用い， $\alpha_{i, j}$ ならびに $\beta_{i, j}$ を次式のように定義する.

$$
\left.\begin{array}{c}
\alpha_{i, 1}=\frac{S_{i, 1,4}}{S_{i, 1,2} \beta_{i-1,1}+S_{i, 1,3} \beta_{i-1,3}+S_{i, 1,4} \beta_{i-1,5}} \\
\alpha_{i, 2} \\
=\frac{\delta_{i}-\left(S_{i, 1,1} \delta_{i-1}+S_{i, 1,2} \beta_{i-1,2}+S_{i, 1,3} \beta_{i-1,4}+S_{i, 1,4} \beta_{i-1,8}+S_{i, 1,5}\right)}{S_{i, 1,2} \beta_{i-1,1}+S_{i, 1,3} \beta_{i-1,3}+S_{i, 1,4} \beta_{i-1,5}} \\
(i=2, \cdots, \quad m-1)
\end{array}\right\}
$$$$
\left.\begin{array}{l}
\beta_{1,2 j-1}=S_{1, j+1,1}-\frac{S_{1, j+1,2} S_{1,1,1}}{S_{1,1,2}} \\
\beta_{1,2 j}=S_{1, j+1,5}+\frac{S_{1, j+1,2}\left(\delta_{1}-S_{1,1,5}\right)}{S_{1,1,2}}
\end{array}\right\}(j=1,2,3)(6)
$$$$
\beta_{i, 2 j-1}=\alpha_{i, 1}\left(S_{i, j+1,2} \beta_{i-1,1}+S_{i, j+1,3} \beta_{i-1,3}+S_{i, j+1,4} \beta_{i-1,5}\right)
$$
$-S_{i, j+1,4}$

$\beta_{i, 2 j}=\alpha_{i, 2}\left(S_{i, j+1,2} \beta_{i-1,1}+S_{i, j+1,3} \beta_{i-1,3}+S_{i, j+1,4} \beta_{i-1,5}\right)$

$$
\begin{aligned}
& +S_{i, j+1,1} \delta_{i-1}+S_{i, j+1,2} \beta_{i-1,2}+S_{i, j+1,3} \beta_{i-1,4} \\
& +S_{i, j+1,4} \beta_{i-1,6}+S_{i, j+1,6} \\
& \quad(i=2, \cdots, m-1, \quad j=1,2,3)
\end{aligned}
$$

自由境界条件を有する軸系船尾端のふたつの未知数, すなわちたわみとたわみ角をそれぞれ $u_{0}, \varphi_{0}$ とすると， 船尾端の状態量は

$$
\{V\}_{0}=\left\{u_{0}, \varphi_{0}, 0,0,1\right\}_{0}^{\mathrm{T}}
$$

支点 1 の変位 $\delta_{1}$ が既知であるから， $\varphi_{0}$ ならびに支点 1 の状態量は次式で表わすととができる.

$$
\varphi_{0}=\frac{\left(\delta_{1}-S_{1,1,1} u_{0}-S_{1,1,6}\right)}{S_{1,1,2}}
$$




$$
\begin{aligned}
\{V\}_{1}^{\mathrm{L}}= & \left\{\begin{array}{c}
\delta_{1} \\
\beta_{1,1} u_{0}+\beta_{1,2} \\
\beta_{1,3} u_{0}+\beta_{1,4} \\
\beta_{1,5} u_{0}+\beta_{1,6}
\end{array}\right\}_{1}^{\mathrm{L}} \\
1 & \\
\{V\}_{1}^{\mathrm{R}} & =\{V\}_{1}^{\mathrm{L}}-\left\{0,0,0, R_{1}, 0\right\}^{\mathrm{T}}
\end{aligned}
$$

支点 2 の変位 $\delta_{2}$ が既知であるから, 未知数 $u_{0}$ は未知 反力 $R_{1}$ で表わすことができ，式 (12) となる.

$$
u_{0}=\alpha_{2,1} R_{1}+\alpha_{2,2}
$$

支点 2 の状態量は

$$
\begin{aligned}
\{V\}_{2}^{\mathrm{L}} & =\left\{\begin{array}{c}
\delta_{2} \\
\beta_{2,1} R_{1}+\beta_{2,2} \\
\beta_{2,3} R_{1}+\beta_{2,4} \\
\beta_{2,5} R_{1}+\beta_{2,6} \\
1
\end{array}\right\}_{2}^{\mathrm{L}} \\
\{V\}_{2}^{\mathrm{R}} & =\{V\}_{2}^{\mathrm{L}}-\left\{0,0,0, R_{2}, 0\right\}^{\mathrm{T}}
\end{aligned}
$$

となる．以下同様な操作を繰り返すと，第 $i$ スパンでは

$$
R_{i-2}=\alpha_{i, 1} R_{i-1}+\alpha_{i, 2} \quad(i=2, \cdots, m-3)
$$

第 $i$ 支点の状態量は

$$
\begin{aligned}
& \{V\}_{i}^{\mathrm{L}}=\left\{\begin{array}{c}
\delta_{i} \\
\beta_{i, 1} R_{i-1}+\beta_{i, 2} \\
\beta_{i, 3} R_{i-1}+\beta_{i, 4} \\
\beta_{i, 5} R_{i-1}+\beta_{i, 6}
\end{array}\right\}_{i}^{\mathrm{L}} \\
& \{V\}_{i}^{\mathrm{R}}=\{V\}_{i}^{\mathrm{L}}-\left\{0,0,0, R_{i}, 0\right\}^{\mathrm{T}}
\end{aligned}
$$

となる，最終の第 $m$ スパンでば，軸系船首端(ステーシ $\exists$ ョ $n$ ) と第 $m-1$ 支点の状態量の間に次式が成立する.

$$
\{V\}_{m}^{\mathrm{L}}=[\mathrm{S}]_{m}\{V\}_{m-1}^{\mathrm{R}}
$$

船首端が自由，固定，単純支持の場合には

$$
\begin{array}{lll}
M=V=0 & \text { (自由) } \\
u=\delta_{m}, \quad \varphi=\theta_{m} & \text { (固定) } \\
u=\delta_{m}, M=0 & \text { (単純支持) }
\end{array}
$$

となるから，乙れら条件を式(18) に適用する．乙こで $W_{1}=S_{m, i, 2} \beta_{m-1,1}+S_{m, i, 3} \beta_{m-1,3}+S_{m, i, 4} \beta_{m-1,5}$ $W_{2}=S_{m, i, 1} \delta_{m-1}+S_{m, i, 2} \beta_{m-1,2}+S_{m, i, 8} \beta_{m-1,4}$ $+S_{m, i, 4} \beta_{m-1,6}+S_{m, i, 5}-\delta_{m}$

$W_{3}=S_{m, j, 2} \beta_{m-1,1}+S_{m, j, 3} \beta_{m-1,3}+S_{m, j, 4} \beta_{m-1,5}$ $\begin{aligned} W_{1}= & S_{m, j, 1} \delta_{m-1}+S_{m, j, 2} \beta_{m-1,2}+S_{m, j, 8} \beta_{m-1,4} \\ & +S_{m, j,} \beta_{m-1,0}+S_{m, j, 5}-\theta_{m}\end{aligned}$

$$
+S_{m, j, 4} \beta_{m-1,6}+S_{m, j, 5}-\theta_{m}
$$

之置くと，最終的に残ったふたつの未知反力 $R_{m-2}, R_{m-1}$ は次式から求めることができる.

$$
\left.\begin{array}{rl}
R_{m-2} & =\frac{S_{m, j, 4} W_{2}-S_{m, i, 4} W_{4}}{S_{m, i, 4} W_{3}-S_{m, j, 4} W_{1}} \\
R_{m-1} & =\frac{W_{2} W_{3}-W_{1} W_{4}}{S_{m, i, 4} W_{3}-S_{m, j, 4} W_{1}}
\end{array}\right\}
$$

式 (20)，(21) の記号は, 自由端では $i=3, j=4, \delta_{m}$ $=\theta_{m}=0$ であり, 固定端では $i=1, j=2$, 単純支持であ れば $i=1, j=3, \theta_{m}=0$ とする.

他の未知数ならびに各支点, 船尾端の状態量は式 (9) 〜(17)功求めることができる. また図 1 に示した，任
意ステーション $j$ から $k$ までを構成する第 $i$ スパン内の ステーションlの状態量は, 次式から求められる.

$$
\{z\}_{l}=[\mathrm{T}]_{l}\{\mathrm{~T}]_{l-1} \cdots[\mathrm{T}]_{j+1}[\mathrm{~T}]_{j}\{V\}_{i-1}^{\mathrm{R}}
$$

2.2 軸受油膜特性の解析 ${ }^{4)}$ 座標系は図 3 亿示 すように軸受船尾端の中央に原点をとり，軸方向船首向 きに $x$ 軸, 水平左舷力向に $y$ 軸, 鉛直上方向に $z$ 軸を定 義する. また軸受中央の最大すきま位置加ら時計の回転 方向に角度 $\theta$, 給油溝位置を表わす角度 $\theta_{\mathrm{G}}$ を $z$ 軸より時 計の回転方向に定義する.

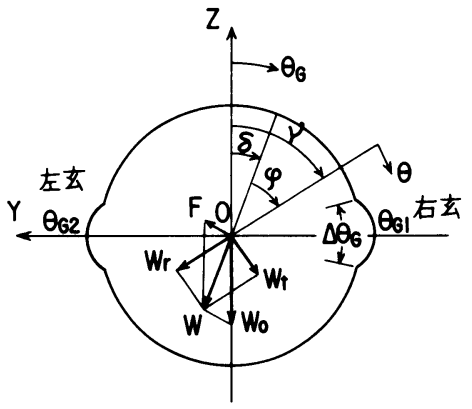

図 3 座標系

圧力を $p$ ，油膜厚さを $h$ ，油の粘性係数を $\mu$ ，軸表面 の周速をUとすると, 静荷重軸受に対するレイノルズ方 程式は次式となる.

$$
\frac{\partial}{\partial \theta}\left(\frac{h^{3}}{\mu} \frac{\partial p}{\partial \theta}\right)+\frac{\partial}{\partial x}\left(\frac{h^{3}}{\mu} \frac{\partial p}{\partial x}\right)=6 U \frac{\partial h}{\partial \theta}
$$

軸受直径を $D(=2 R, R$ は半径 $)$, 軸受幅を $L$, 軸の毎 秒回転数を $n$, 回転角速度を $\omega$, 軸受半径すきまを $C_{\mathrm{r}}$, 軸受荷重を $W$ として以下に示す無次元量を定義する.

$$
\left.\begin{array}{l}
\bar{x}=x / L, \quad \bar{\theta}=\theta / \pi D, \quad H=h / C_{\mathrm{r}}, \quad \bar{p}=p /\left(\frac{R}{C_{\mathrm{r}}}\right)^{2} \mu \omega \\
S=\left(\frac{R}{C_{\mathrm{r}}}\right)^{2} \mu n / p_{\mathrm{m}}, \quad \bar{W}=W / 2 \pi\left(\frac{R}{C_{\mathrm{r}}}\right)^{2} \mu \omega R L
\end{array}\right\}
$$

$S$ はゾンマフェルト数, $p_{\mathrm{m}}$ は軸受平均面圧 $(W / D L)$ を 表わす。

上記無次元量ならびに式 (25)で表わされる新変数 $q^{6)}$ を用いると, 式(23)は式(26)に変換できる.

$$
\begin{aligned}
& q=\bar{p} H^{\frac{3}{2}} \\
& \frac{\partial^{2} q}{\partial \bar{\theta}^{2}}+\left(\frac{\pi D}{L}\right)^{2} \frac{\partial^{2} q}{\partial \bar{x}^{2}}-\frac{3}{4 H^{2}}\left[\left(\frac{\partial H}{\partial \bar{\theta}}\right)^{2}+\left(\frac{\pi D}{L}\right)^{2}\left(\frac{\partial H}{\partial \bar{x}}\right)^{2}\right. \\
& \left.+2 H\left\{\frac{\partial^{2} H}{\partial \bar{\theta}^{2}}+\left(\frac{\pi D}{L}\right)^{2} \frac{\partial^{2} H}{\partial \bar{x}^{2}}\right\}\right] q=\frac{2 \pi}{H^{\frac{3}{2}}} \frac{\partial H}{\partial \bar{\theta}}
\end{aligned}
$$

軸のたわみを考慮するために，軸は図 4 に示すように 軸方向に奇数等分割された軸受区間内で，軸心のたわみ 曲線に沿って連続的に折れ曲がっており，かつ軸受中心 線に直角な軸の横断面は近似的に円形であると仮定する。

アライメント計算で求められたステーション $i-1$ と $i$ の $y, z$ 座標をそれぞれ $\left(y_{i-1}, z_{i-1}\right),\left(y_{i}, z_{i}\right)$ とすると, 軸受内の分割区間中央の偏心率は近似的に 


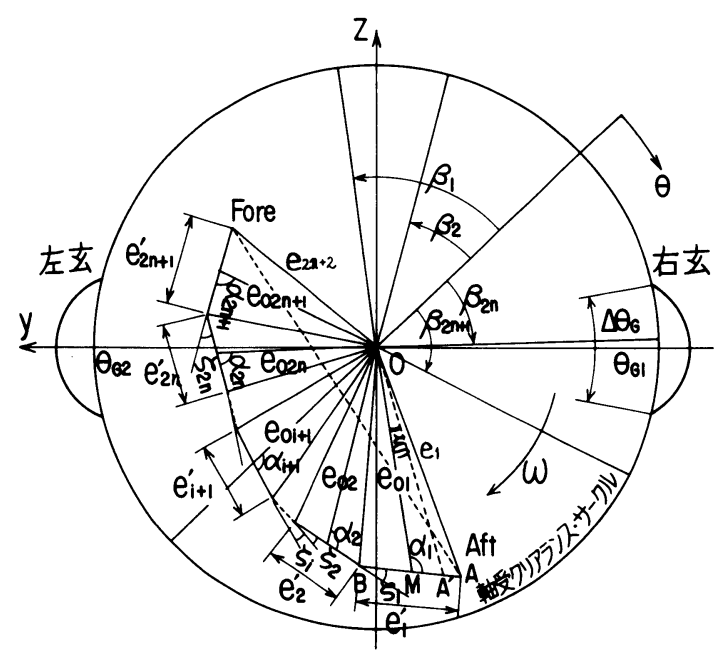

図 4 軸受内の軸心姿勢

$$
\varepsilon_{0 i}=\frac{1}{C_{\mathrm{r}}}\left[\left(\frac{y_{i-1}+y_{i}}{2}\right)^{2}+\left(\frac{z_{i-1}+z_{i}}{2}\right)^{2}\right]^{\frac{1}{2}}=\frac{e_{0 i}}{C_{\mathrm{r}}}
$$

となり，軸心の軸方向投影長さは

$$
\varepsilon_{i}{ }^{\prime}=\frac{1}{C_{\mathrm{r}}}\left[\left(y_{i}-y_{i-1}\right)^{2}+\left(z_{i}-z_{i-1}\right)^{2}\right]^{\frac{1}{2}}=\frac{e_{i}{ }^{\prime}}{C_{\mathrm{r}}}
$$

となるままた軸心と分割区間中央を通る直径とのなす角 $\alpha$ は次式で与えられる.

$$
\alpha_{i}=\tan ^{-1}\left[\frac{\left(\frac{z_{i-1}+z_{i}}{y_{i-1}+y_{i}}\right)-\left(\frac{z_{i}-z_{i-1}}{y_{i}-y_{i-1}}\right)}{1+\left(\frac{z_{i-1}+z_{i}}{y_{i-1}+y_{i}}\right)\left(\frac{z_{i}-z_{i-1}}{y_{i}-y_{i-1}}\right)}\right]
$$

図 4 に示したように, 軸受幅を $2 n+1$ 個の奇数等分割 した各分割区間内の油膜厚さを, 近似的に次式で与える.

$$
\begin{gathered}
H_{i}(\bar{\theta}, \bar{x})=1+\varepsilon_{0 i} \cos \left(2 \pi \bar{\theta}-\beta_{i}\right) \\
+(2 n+1) \varepsilon_{i}^{\prime}\left\{\bar{x}-\frac{2 i-1}{2(2 n+1)}\right\} \cos \left(2 \pi \bar{\theta}-\alpha_{i}-\beta_{i}\right) \\
(i=1,2, \cdots, 2 n+1, \quad n=0,1,2, \cdots)
\end{gathered}
$$

式(30)の $\beta_{i}$ は式(31)で与えられる.

$\beta_{i}=\alpha_{n+1}-\alpha_{i}-\sum_{i=i}^{n} \zeta_{i} \quad(i=1, \cdots, n)$

$\beta_{n+1}=0$

$\beta_{i}=\alpha_{n+1}-\alpha_{i}-\sum_{i=n+1}^{i-1} \zeta_{i}(i=n+2, \cdots, 2 n+1)$

$\zeta_{i}=\pi-\left[\sin ^{-1}\left\{\frac{\varepsilon_{0 i}}{\varepsilon_{i+1}} \sin \left(\alpha_{i}\right)\right\}+\sin ^{-1}\left\{\frac{\varepsilon_{0 i+1}}{\varepsilon_{i+1}} \sin \left(\alpha_{i+1}\right)\right\}\right]$

ここに $\varepsilon_{0} i$ は分割区間 $i$ の中央の偏心率, $\varepsilon_{i+1}$ は分割 区間 $i$ の船首側偏心率を示す.

図 5 に示した軸受内径が軸方向で直線的に変化するス カート型軸受 ${ }^{7)}$ の油膜厚さは, 近似的に式 (32) で与えら れる.

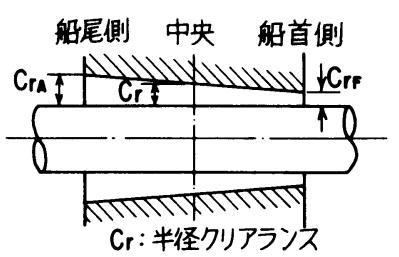

図 5 スカート型軸受

$$
\begin{aligned}
& H_{i}(\bar{\theta}, \bar{x})=\frac{2 K}{K+1}+2\left(\frac{1-K}{1+K}\right) \bar{x}+\varepsilon_{0 i} \cos \left(2 \pi \bar{\theta}-\beta_{i}\right) \\
& +(2 n+1) \varepsilon_{i}{ }^{\prime}\left\{\bar{x}-\frac{2 i-1}{2(2 n+1)}\right\} \cos \left(2 \pi \bar{\theta}-\alpha_{i}-\beta_{i}\right)
\end{aligned}
$$

ここに

$$
K=\frac{C_{\mathrm{rA}}}{C_{\mathrm{rF}}}
$$

であり， $C_{\mathrm{rF}}, C_{\mathrm{rA}}$ はそれぞれ軸受船首端，船尾端の半 径すきまであり， $K=1$ のとき式 (32) は式 (30)に一致 する.なお式(32)の偏心率は $K=1$ に対する值で与えな ければならない.

式 (26) の圧力計算は差分法を用いて行う. 油膜圧力 が求まれば, 軸受圧力は次式を用いて求める.

$$
\begin{aligned}
& \bar{W}_{\mathrm{r}}=\int_{0}^{1} \int_{0}^{1} \bar{p}(\bar{\theta}, \bar{x}) \cos (2 \pi \bar{\theta}) d \bar{\theta} d \bar{x} \\
& \bar{W}_{\mathrm{t}}=\int_{0}^{1} \int_{0}^{1} \bar{p}(\bar{\theta}, \bar{x}) \sin (2 \pi \bar{\theta}) d \bar{\theta} d \bar{x} \\
& \bar{W}=\sqrt{\bar{W}_{\mathrm{r}}^{2}+\bar{W}_{\mathrm{t}}^{2}}=W / 2 \pi\left(\frac{R}{C_{\mathrm{r}}}\right)^{2} \mu \omega R L \\
& \varphi=\tan ^{-1}\left(-\frac{\bar{W}_{\mathrm{t}}}{\bar{W}_{\mathrm{r}}}\right) .
\end{aligned}
$$

$\bar{W}$ は軸受反力, $\bar{W}_{\mathrm{r}}, \bar{W}_{\mathrm{t}}$ は軸受反力の半径方向成分と 接線方向成分, $\varphi$ は偏角を表わす.

計算で得られた軸受特性を，動的アライメント計算に 適用するには，あらかじめ各種条件にもとづく軸受特性 を求め, てれをデータ・バンクとして格納し, 動的アラ イメント計算に適合する值を補間法によって求める.

2.3 プロペラ・フォースならびに曲げモーメン 卜 プロペラが不均一な伴流中を回転することにより 流体から受ける静的な水力作用は，準定常理論によると 次式で与えられる ${ }^{5)}$.

$$
\begin{aligned}
& 2 F_{y} R / Q=A_{\mathrm{q}} w_{\mathrm{ac}}-\left(2+A_{\mathrm{q}}\right) w_{\mathrm{uc}} V_{\mathrm{s}} / u \\
& 2 F_{\mathrm{z}} R / Q=-A_{\mathrm{q}} w_{\mathrm{as}}+\left(2+A_{\mathrm{q}}\right) w_{\mathrm{us}} V_{\mathrm{s}} / u \\
& 2 B_{\mathrm{y}} / T R=A_{\mathrm{t}} w_{\mathrm{ac}}-\left(2+A_{\mathrm{t}}\right) w_{\mathrm{uc}} V_{\mathrm{s}} / u \\
& 2 B_{\mathrm{z}} / T R=-A_{\mathrm{t}} w_{\mathrm{as}}+\left(2+A_{\mathrm{t}}\right) w_{\mathrm{us}} V_{\mathrm{s}} / u \\
& w_{\mathrm{ac}}=w_{\mathrm{a} 1} \cos \varphi_{\mathrm{a} 1} /\left(1-w_{\mathrm{a} 0}\right) \\
& w_{\mathrm{a} \mathrm{s}}=w_{\mathrm{a} 1} \sin \varphi_{\mathrm{a} 1} /\left(1-w_{\mathrm{a} 0}\right) \\
& w_{\mathrm{uc}}=w_{\mathrm{u} 1} \cos \varphi_{\mathrm{u} 1} \\
& w_{\mathrm{us}}=w_{\mathrm{u} 1} \sin \varphi_{\mathrm{u} 1} \\
& A_{\mathrm{q}}=-\frac{J}{K_{\mathrm{q}}} \frac{d K_{\mathrm{q}}}{d J}, \quad A_{\mathrm{t}}=-\frac{J}{K_{\mathrm{t}}} \frac{d K_{\mathrm{t}}}{d J}
\end{aligned}
$$


$F_{y}, F_{z}$ は $y, z$ 軸方向に作用する力， $B_{y}, B_{z}$ は $y, z$ 軸回りに作用する曲げモーメント，Rはプロペラ半径 $(0.7 r / R), Q$ は平均トルク,$T$ は平均スラスト, $V_{\mathrm{s}}$ は 船速， $u$ は半径 $R$ 上のプロペラ周速， $J$ は前進係数， $K_{\mathbf{t}}$ はスラスト係数， $K_{\mathrm{q}}$ はトルク係数， $w_{1}, \varphi_{1}$ は伴流係数 の 1 次の調和項ならびに位相角， $w_{\mathrm{a} 0}$ は平均伴流係数を 表わす．また添子 $\mathrm{a}$ は軸方向， $\mathrm{u}$ は円周方向を表わす.

動的アライメント計算では，伴流分布のパターン形状 と，プロペラ・フォースの関係が特に注目される. 伴流 分布をパターン化し，てれよりべアリング・フォースを 求め, 推進軸系の横振動に適用した例が安濃田・葉山 ${ }^{8)}$ によって行われた. こてであ同様なパターン化を行い， プロペラ・フォースを求める.

軸方向伴流係数の一般的なパターンを図 6 亿示す. $W$ は伴流係数， $r, \delta, \varphi, \eta, \theta$ は角度を表的す. 図6 の伴流 パターンを調和解析すると次式となる。

$$
\begin{aligned}
& a_{\mathrm{ak}}=\frac{1}{\pi k^{2}}\left[\frac{\left(W_{\mathrm{T}}-W_{\mathrm{A} 2}\right)}{\left(\varphi_{\mathrm{A}}+\delta_{\mathrm{A}}\right)}\left\{\cos k\left(\gamma_{\mathrm{A}}+\delta_{\mathrm{A}}\right)-\cos k\left(\gamma_{\mathrm{A}}-\varphi_{\mathrm{A}}\right)\right\}\right. \\
& -\frac{\left(W_{\mathbf{T}}-W_{\mathrm{A} 1}\right)}{\left(\varphi_{\mathrm{A}}-\delta_{\mathrm{A}}\right)}\left\{\cos k\left(\varphi_{\mathrm{A}}+r_{\mathrm{A}}\right)-\cos k\left(\gamma_{\mathrm{A}}+\delta_{\mathrm{A}}\right)\right\} \\
& -\frac{\left(W_{\mathrm{A} 1}-W_{\mathrm{S}}\right)}{\theta_{\mathrm{A}}}\left\{\cos k\left(\varphi_{\mathrm{A}}+\gamma_{\mathrm{A}}+\theta_{\mathrm{A}}\right)-\cos k\left(\varphi_{\mathrm{A}}+\gamma_{\mathrm{A}}\right)\right\} \\
& +\frac{\left(W_{\mathrm{A} 2}-W_{\mathrm{S}}\right)}{\eta_{\mathrm{A}}}\left\{\cos k\left(\gamma_{\mathrm{A}}-\varphi_{\mathrm{A}}\right)-\cos k\left(\gamma_{\mathrm{A}}-\varphi_{\mathrm{A}}-\eta_{\mathrm{A}}\right)\right\} \\
& +(-1)^{k}<\frac{\left(W_{\mathrm{B} 1}-W_{\mathrm{S}}\right)}{\theta_{\mathrm{B}}}\left\{\cos k\left(\gamma_{\mathrm{B}}-\varphi_{\mathrm{B}}\right)-\cos k\left(\gamma_{\mathrm{B}}-\varphi_{\mathrm{B}}-\theta_{\mathrm{B}}\right)\right\} \\
& +\frac{\left(W_{\mathrm{B}}-W_{\mathrm{B} 1}\right)}{\left(\varphi_{\mathrm{B}}+\delta_{\mathrm{B}}\right)}\left\{\cos k\left(\gamma_{\mathrm{B}}+\delta_{\mathrm{B}}\right)-\cos k\left(\gamma_{\mathrm{B}}-\varphi_{\mathrm{B}}\right)\right\} \\
& -\frac{\left(W_{\mathrm{B}}-W_{\mathrm{B} 2}\right)}{\left(\varphi_{\mathrm{B}}-\delta_{\mathrm{B}}\right)}\left\{\cos k\left(\gamma_{\mathrm{B}}+\varphi_{\mathrm{B}}\right)-\cos k\left(\gamma_{\mathrm{B}}+\delta_{\mathrm{B}}\right)\right\} \\
& \left.\left.-\frac{\left(W_{\mathrm{B} 2}-W_{\mathrm{S}}\right)}{\eta_{\mathrm{B}}}\left\{\cos k\left(\gamma_{\mathrm{B}}+\varphi_{\mathrm{B}}+\eta_{\mathrm{B}}\right)-\cos k\left(\gamma_{\mathrm{B}}+\varphi_{\mathrm{B}}\right)\right\}\right\rangle\right] \\
& b_{\mathrm{ak}}=\frac{1}{\pi k^{2}}\left\{\frac{\left(W_{\mathrm{T}}-W_{\mathrm{A} 2}\right)}{\left(\varphi_{\mathrm{A}}+\delta_{\mathrm{A}}\right)}\left\{\sin k\left(r_{\mathrm{A}}+\delta_{\mathrm{A}}\right)-\sin k\left(\gamma_{\mathrm{A}}-\varphi_{\mathrm{A}}\right)\right\}\right. \\
& -\frac{\left(W_{\mathrm{T}}-W_{\mathrm{A} 1}\right)}{\left(\varphi_{\mathrm{A}}-\delta_{\mathrm{A}}\right)}\left\{\sin k\left(\varphi_{\mathrm{A}}+\gamma_{\mathrm{A}}\right)-\sin k\left(\gamma_{\mathrm{A}}+\delta_{\mathrm{A}}\right)\right\} \\
& -\frac{\left(W_{\mathrm{A} 1}-W_{\mathrm{S}}\right)}{\theta_{\mathrm{A}}}\left\{\sin k\left(\varphi_{\mathrm{A}}+\gamma_{\mathrm{A}}+\theta_{\mathrm{A}}\right)-\sin k\left(\varphi_{\mathrm{A}}+\gamma_{\mathrm{A}}\right)\right\} \\
& +\frac{\left(W_{\mathrm{A} 2}-W_{\mathrm{S}}\right)}{\eta_{\mathrm{A}}}\left\{\sin k\left(\gamma_{\mathrm{A}}-\varphi_{\mathrm{A}}\right)-\sin k\left(r_{\mathrm{A}}-\varphi_{\mathrm{A}}-\eta_{\mathrm{A}}\right)\right\} \\
& +(-1)^{k}<\frac{\left(W_{\mathrm{B}}-W_{\mathrm{S}}\right)}{\theta_{\mathrm{B}}}\left\{\sin k\left(r_{\mathrm{B}}-\varphi_{\mathrm{B}}\right)-\sin k\left(r_{\mathrm{B}}-\varphi_{\mathrm{B}}-\theta_{\mathrm{B}}\right)\right\} \\
& +\frac{\left(W_{\mathrm{B}}-W_{\mathrm{B}}\right)}{\left(\varphi_{\mathrm{B}}+\delta_{\mathrm{B}}\right)}\left\{\sin k\left(\gamma_{\mathrm{B}}+\delta_{\mathrm{B}}\right)-\sin k\left(\gamma_{\mathrm{B}}-\varphi_{\mathrm{B}}\right)\right\} \\
& -\frac{\left(W_{\mathrm{B}}-W_{\mathrm{B} 2}\right)}{\left(\varphi_{\mathrm{B}}-\delta_{\mathrm{B}}\right)}\left\{\sin k\left(\gamma_{\mathrm{B}}+\varphi_{\mathrm{B}}\right)-\sin k\left(\gamma_{\mathrm{B}}+\delta_{\mathrm{B}}\right)\right\} \\
& -\frac{\left(W_{\mathrm{B} 2}-W_{\mathrm{S}}\right)}{\eta_{\mathrm{B}}}\left\{\sin k\left(\gamma_{\mathrm{B}}+\varphi_{\mathrm{B}}+\eta_{\mathrm{B}}\right)-\sin k\left(\gamma_{\mathrm{B}}+\varphi_{\mathrm{B}}\right)|\rangle\right] \\
& (k=0,1,2, \cdots)
\end{aligned}
$$

式(38)の $a_{\mathrm{ak}}, b_{\mathrm{ak}}$ はそれぞれ $\cos$ 成分， $\sin$ 成分の

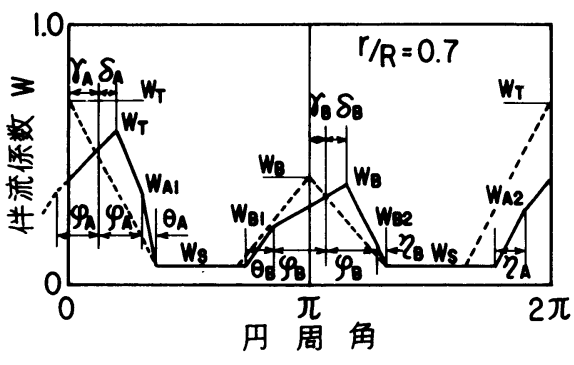

図 6 一般的な軸方向伴流分布

係数を表わし，てれより伴流係数ならびに位相角は

$$
\begin{aligned}
& w_{\mathrm{a} 0}=a_{\mathrm{a} 0} / 2 \\
& w_{\mathrm{ak}}=\sqrt{a_{\mathrm{ak}}{ }^{2}+b_{\mathrm{ak}}{ }^{2}}, \quad \varphi_{\mathrm{ak}}=\tan ^{-1}\left(b_{\mathrm{ak}} / a_{\mathrm{ak}}\right)
\end{aligned}
$$

となる．パターンを図 6 の破線で示したようにさらに簡 単化すると，係数 $a_{\mathrm{ak}}, b_{\mathrm{ak}}$ は次式となる.

$$
\left.\begin{array}{rl}
a_{\mathrm{ak}}= & \frac{2\left(W_{\mathrm{T}}-W_{\mathrm{S}}\right)}{\pi k^{2} \varphi_{\mathrm{A}}}\left(1-\cos k \varphi_{\mathrm{A}}\right) \\
& +\frac{(-1)^{k} 2\left(W_{\mathrm{B}}-W_{\mathrm{S}}\right)}{\pi k^{2} \varphi_{\mathrm{B}}}\left(1-\cos k \varphi_{\mathrm{B}}\right) \\
b_{\mathrm{ak}}= & 0
\end{array}\right\}
$$

円周方向伴流係数の一般的なパターンを図 7 に示す これを調和解析すると次式となる

$$
\begin{aligned}
& a_{\mathrm{uk}}=\frac{1}{\pi k^{2}}\left[\frac{\left(W_{\mathrm{t} 1}-W_{\mathrm{S}}\right)}{\varphi_{\mathrm{t} 1}}\left\{\cos k \varphi_{\mathrm{t} 1}-1\right\}\right. \\
& +\frac{\left(W_{\mathrm{B} 1}-W_{\mathrm{t} 1}\right)}{\left(\pi-\varphi_{\mathrm{t} 1}-\varphi_{\mathrm{B} 1}\right)}\left\{(-1)^{k} \cos k \varphi_{\mathrm{B} 1}-\cos k \varphi_{\mathrm{t} 1}\right\} \\
& -(-1)^{k} \frac{W_{\mathrm{B} 1}}{\left(\varphi_{\mathrm{B} 1}-\varphi_{\mathrm{B}}\right)}\left\{\cos k \varphi_{\mathrm{B}}-\cos k \varphi_{\mathrm{B} 1}\right\} \\
& +(-1)^{k} \frac{W_{\mathrm{B} 2}}{\left(\varphi_{\mathrm{B} 2}+\varphi_{\mathrm{B}}\right)}\left\{\cos k \varphi_{\mathrm{B} 2}-\cos k \varphi_{\mathrm{B}}\right\} \\
& +\frac{\left(W_{\mathrm{t} 2}-W_{\mathrm{B} 2}\right)}{\left(\pi-\varphi_{\mathrm{B} 2}-\varphi_{\mathrm{t} 2}\right)}\left\{\cos k \varphi_{\mathrm{t} 2}-(-1)^{k} \cos k \varphi_{\mathrm{B} 2}\right\} \\
& \left.+\frac{\left(W_{\mathrm{S}}-W_{\mathrm{t} 2}\right)}{\varphi_{\mathrm{t} 2}}\left\{1-\cos k \varphi_{\mathrm{t} 2}\right\}\right] \\
& b_{\mathrm{uk}}=\frac{1}{\pi k^{2}}\left[\frac{\left(W_{\mathrm{t} 1}-W_{\mathrm{S}}\right)}{\varphi_{\mathrm{t} 1}} \sin k \varphi_{\mathrm{t} 1}\right. \\
& -\frac{\left(W_{\mathrm{B} 1}-W_{\mathrm{t} 1}\right)}{\left(\pi-\varphi_{\mathrm{t} 1}-\varphi_{\mathrm{B} 1}\right)}\left\{(-1)^{k} \sin k \varphi_{\mathrm{B} 1}+\sin k \varphi_{\mathrm{t} 1}\right\} \\
& +(-1)^{k} \frac{W_{\mathrm{B} 1}}{\left(\varphi_{\mathrm{B} 1}-\varphi_{\mathrm{B}}\right)}\left\{\sin k \varphi_{\mathrm{B}}-\sin k \varphi_{\mathrm{B} 1}\right\} \\
& +(-1)^{k} \frac{W_{\mathrm{B} 2}}{\left(\varphi_{\mathrm{B} 2}+\varphi_{\mathrm{B}}\right)}\left\{\sin k \varphi_{\mathrm{B} 2}+\sin k \varphi_{\mathrm{B}}\right\} \\
& -\frac{\left(W_{\mathrm{t} 2}-W_{\mathrm{B} 2}\right)}{\left(\pi-\varphi_{\mathrm{B} 2}-\varphi_{\mathrm{t} 2}\right)}\left\{\sin k \varphi_{\mathrm{t} 2}+(-1)^{k} \sin k \varphi_{\mathrm{B} 2}\right\} \\
& \left.+\frac{\left(W_{\mathrm{s}}-W_{\mathrm{t} 2}\right)}{\varphi_{\mathrm{t} 2}} \sin k \varphi_{\mathrm{t} 2}\right] \\
& \begin{array}{c}
(k=0,1,2, \cdots) \\
w_{\mathrm{uk}}=\sqrt{a_{\mathrm{uk}}^{2}+b_{\mathrm{uk}}^{2},} \varphi_{\mathrm{uk}}=\tan ^{-1}\left(b_{\mathrm{uk}} / a_{\mathrm{uk}}\right)
\end{array}
\end{aligned}
$$

さらに図 7 の破線で示したパターンについて求めると 


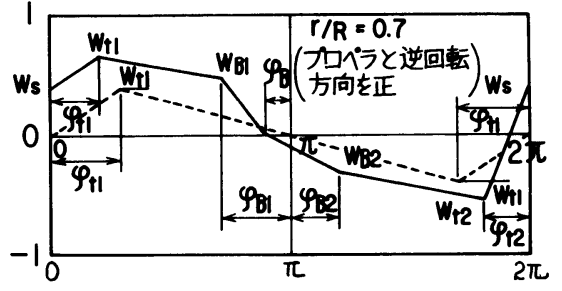

図 7 円周方向伴流分布

$$
\begin{aligned}
& a_{\mathrm{uk}}=0 \\
& b_{\mathrm{uk}}=\frac{2 W_{\mathrm{t} 1}}{\pi k^{2}} \sin k \varphi_{\mathrm{t} 1}\left[\frac{1}{\varphi_{\mathrm{t} 1}}+\frac{1}{\pi-\varphi_{\mathrm{t} 1}}\right]
\end{aligned}
$$

となる. 以上で伴流係数ならびに位相角が求まり, これ にプロペラ特性を考慮すれば，式 (35)〜式 (37) により プロペラ・フォースを求めるととができる.

2.4 計算のフロー・チャート 動的アライメン 卜計算の流れを表 1 に示す. 個々の動的アライメント計 算の流れのなかで, 軸受油膜特性を求めていては，計算 時間が多くかかり実用的でない. したがって，あらかじ め種々の条件 $(L / D$, 軸の傾き $(q)$, 軸のたわみ $(\lambda)$, 給 油溝の位置 $\left(\theta_{\mathrm{G}}\right)$, 給油溝の角度 $\left.\left(\Delta \theta_{\mathrm{G}}\right)\right)$ について軸受特 性を求め, これをデータ・バンクとして保存する. この データとアライメント計算で得られた值とが一致すれば, 軸系の状態量を出力する. 圧力分布の状態が知りたりれ ば，上記計算で得られた軸心位置を用いて式(26)の計算 在行う。

なお中間軸受の軸心位置は外力の影響が小さいと思わ れるため, 軸の傾きならびにたわみのない通常のジャー

表 1 計算のフローチャート

(S)

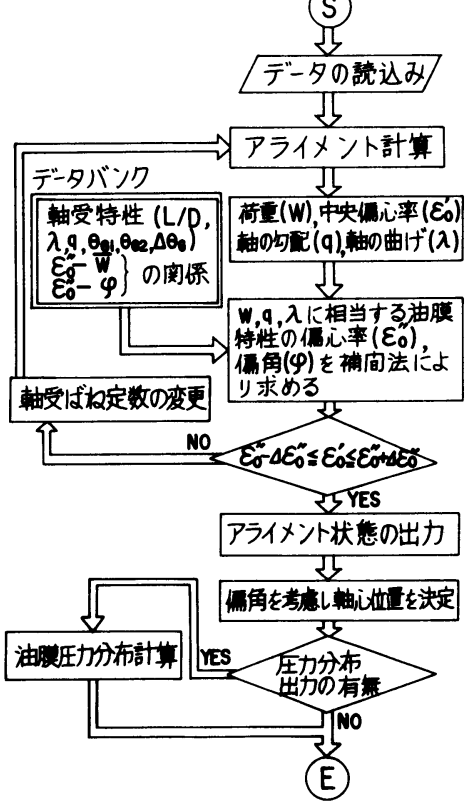

ナル軸受理論で，得られる特性から決定する.また二 重底の変形による軸受オフセット量の変化は, SakaiKanda $^{9)}$ が簡単で便利な計算法を提供しているため, こ れを利用する.

\section{3. 計算結果ならびに検討}

3.1 軸受油膜特性 データ・バンクに格納する油 膜特性の一例を図 8 加図 13 に示す. 図 8 , 図 9 は偏心 率之軸受負荷容量の関係を, 軸の傾き $\left(q=e^{\prime} / 2 C_{\mathrm{r}}, e^{\prime}\right.$ は軸心の軸方向投影長さ)をパラメータとして示してい る. 図から明らかなように傾き $q$ が小さいと， $\alpha$ の大き さによる差異は少ないが， $q$ が大きくなると $\alpha$ の違いに よる差が大きくなる.

軸にたわみ $(\lambda)$ がある場合の偏心率と負荷容量の関係

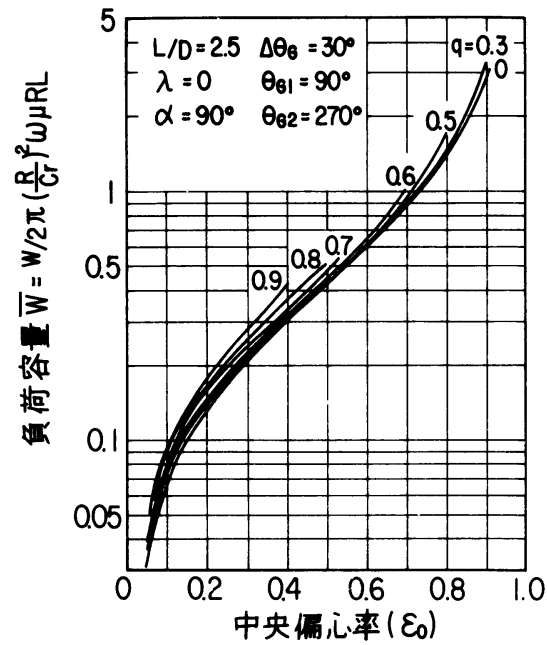

困 8 偏心率之負荷容量の関係

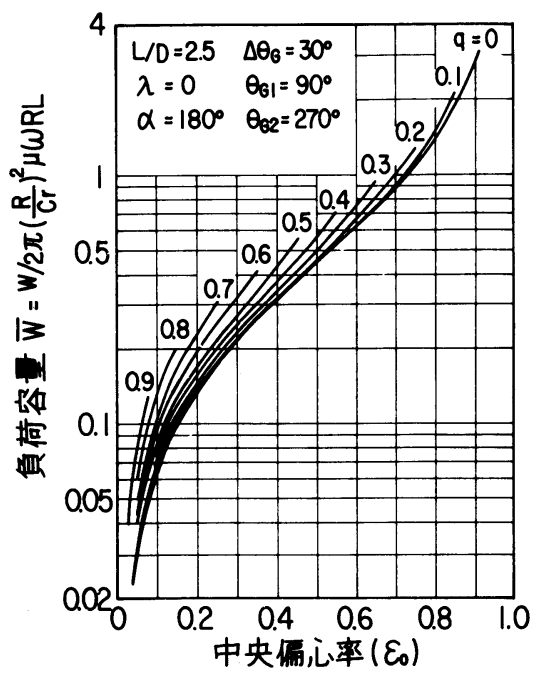

図 9 偏心率と負荷容量の関係 


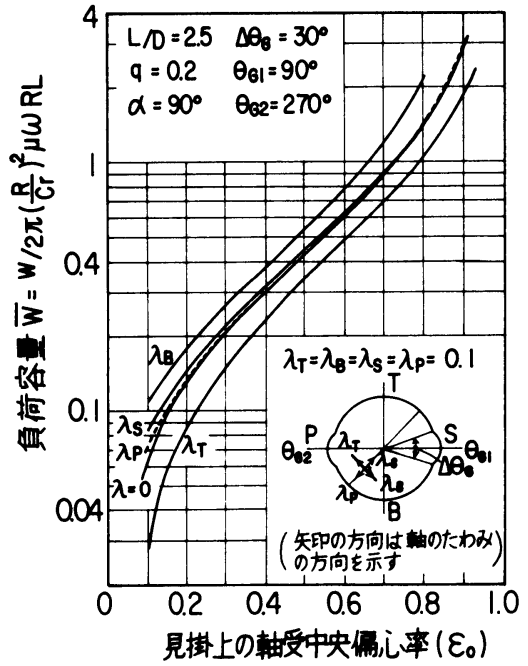

困 10 偏心率と負荷容量の関係

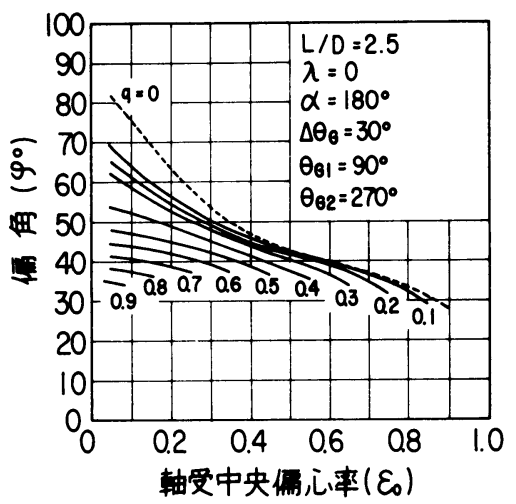

図 11 偏心率と偏角の関係

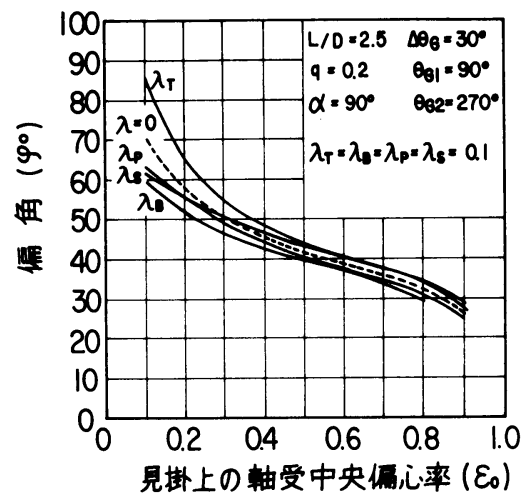

困 12 偏心率之偏角の関係

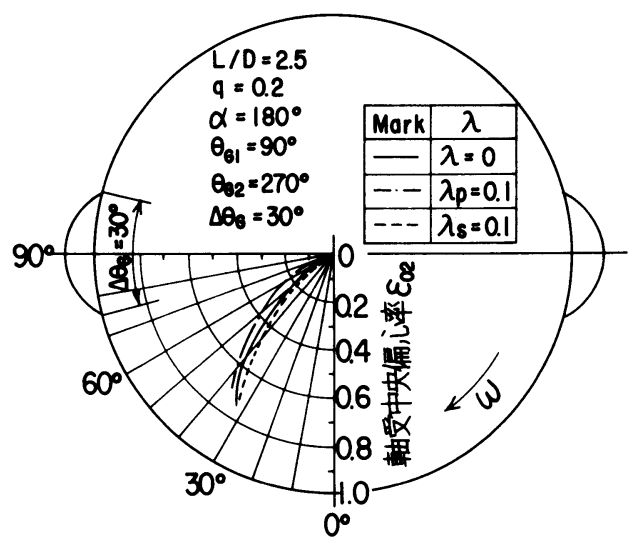

図 13 軸受中央の軸心軌跡

は図 10 に示すとおりである. 軸のたわみの方向はあら ゆる方向が考えられるが，ここでは代表的な例について 示した. 図に示した見掛上の軸受中央偏心率とは，軸受 船首端之船尾端の軸心を結んだ直線上における，軸受中 央の偏心率を意味する.

偏心率之偏角の関係を傾き $q$ をパラメータとして表示 すれば図 11，図 12 となる。また図 13 は軸の傾きならび にたわみを有する場合の，軸心軌跡の一例である.

以上のような特性をデータ・バンクとして保存する. このほかにも $L / D$, 給油溝位置 $\left(\theta_{\mathrm{G} 1}, \theta_{\mathrm{G} \mathbf{2}}\right)$, 給油溝角 度 $\left(\Delta \theta_{\mathrm{G}}\right)$ などをパラメータとした特性か加わるが），乙 こでは油膜特性について論じることが本来の目的ではな いため，てれ以上は言及しない.

3.2 伴流パターンとプロペラ・フォースの特性 式(35) に示したように，プロペラ特性が同一であれば， プロペラ・フォースは伴流分布だけの関数となる. した がって, 式(36)で表わされる数値の比較から, プロペラ ・フォースの定性的な比較検討を行う.

たとえば図 14 に示すように，（a）プロペラ円下部の 伴流係数の影榔，（b）プロペラ円下部の伴流パターンの すそ野の広がりの影響，（c）プロペラ円上部の伴流パタ ーンのすそ野の広がりの影響, (d) プロペラ円上部の伴 流係数の影響についてしらべるために，伴流パターンの

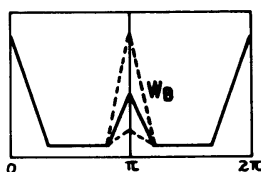

(a) W $W_{B}$ 変更

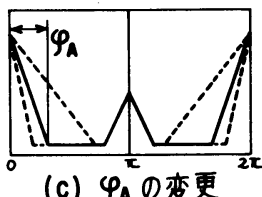

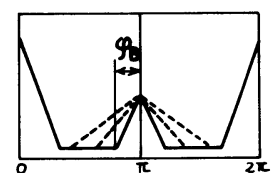

(b) $\varphi_{B}$ の变更

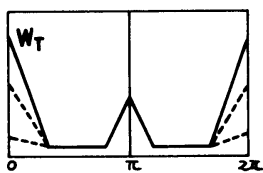

(d) $W_{\top}$ の変更
困 14 伴流分布の変化 

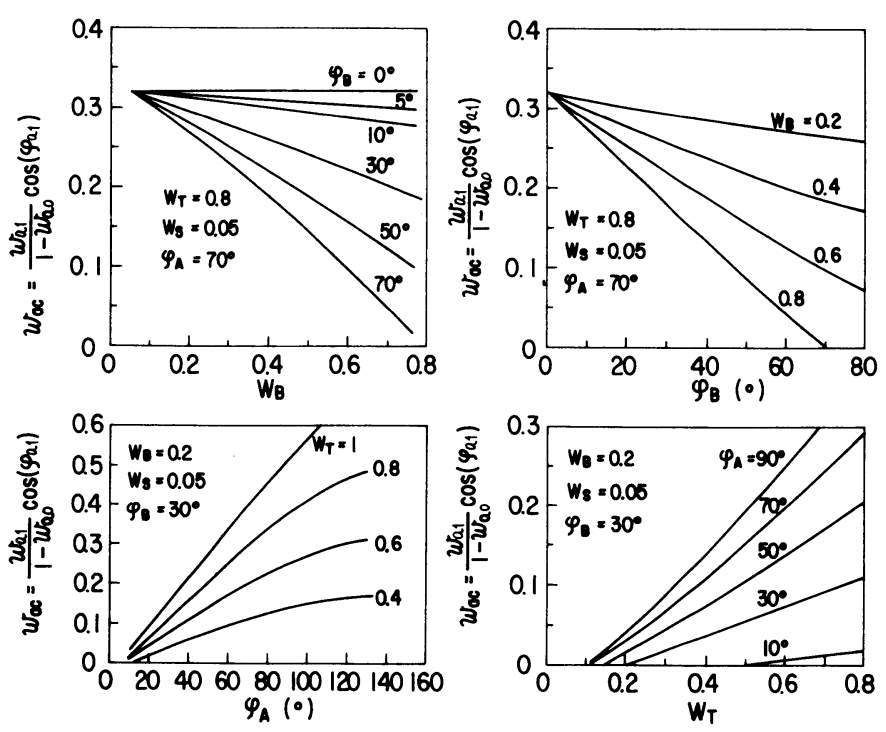

図 15 軸方向伴流分布とプロペラ・フォース係数

一部を破線で示したように変更すると, 図 15 に示した 結果となる.

これによると，プロペラ円下部のすそ野のひろがり角 $\varphi_{\mathrm{B}}$ が一定であれば, 伴流係数 $W_{\mathrm{B}}$ が小さいほど $w_{\mathrm{ac}}$, す なわちプロペラ・フォースの $F_{y}, B_{y}$ は大きくなる. $W_{\mathrm{B}}$ が一定であれば， $\varphi_{\mathrm{B}}$ が小さいほど $w_{\mathrm{ac}}$ は大きくなる。

プロペラ円上部の伴流係数 $\left(W_{\mathrm{T}}\right)$ のすそ野のひろがり角 $\left(\varphi_{\mathrm{A}}\right)$ が一定であれば, $W_{\mathrm{T}}$ が大きいほど $w_{\mathrm{ac}}$ は大きくなる. $W_{\mathrm{T}}$ が一定であれば, $\varphi_{\mathrm{A}}$ が大きいほど $w_{\mathrm{ac}}$ は大きくなる.

図 14 に示した伴流パターンは，船 体中心線 ( $z$ 軸) に関して対称な分布之 なっているため $w_{\mathrm{as}}$ の項はない. した

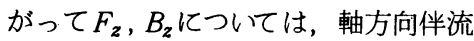
係数はなんら寄与しないことになる.

図 7 の破線で示した円周方向伴流パ ターンについて, 同様な検討を行った 結果を図 16 に示す. 図 7 に示したパ ターンは, 船体中心線に関して逆対称 となるため， $w_{\mathrm{us}}$ の項だけとなる． $w_{\mathrm{us}}$ はプロペラ・フォースの $F_{z}, B_{z}$ の大き さに関係する. 図 16 によると, 伴流 係数 $W_{\mathrm{tl}}$ が大きいほよ゙ $w_{\mathrm{us}}$ は大きくな り, $\varphi_{\mathrm{t} 1}$ の影響は少ない.

以上より, 軸方向伴流係数はプロペ ラ円上部の伴流係数之そのすそ野の広 がりが大きく，かつプロペラ円下部の 伴流係数が小さいほどプロペラ・フォ 一スが大きくなり, 円周方向伴流係数 は，係数が大きいほどプロペラ・フォ ースが大きくなる傾向にあるといえる.

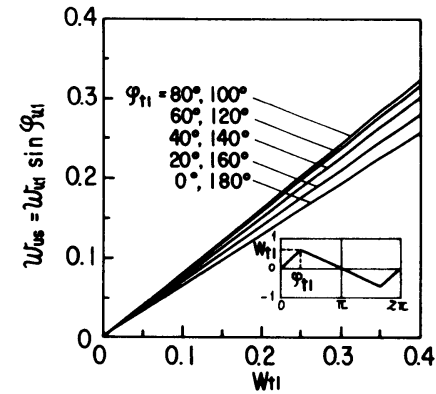

図 16 円周方向伴流分布之 プロペラ・フォース 係数

3.3 実船への適用同一の船舶に 対して，四種類の伴流パターンを適用した 例について検討する.

対象船はディーゼル機関を主機とする一 軸バルク・キャリアで，主要目は以下のと おりである.

載荷重量：34,600MT

定格出力： $10,500 \mathrm{PS} \times 130 \mathrm{rpm}\left\{7,723 \mathrm{~kW} \times 130 \mathrm{~min}^{-1}\right\}$ (M. C.O)

プロペラ：直径 $5.55 \mathrm{~m}$, 重量 $12.160 \mathrm{kgf}\{119.2 \mathrm{kN}\}$

プロペラ軸： $460 \phi \mathrm{mm} \times 7,040 \mathrm{~mm}$

対象船の軸系装置図を図17亿，適用する伴流パターンを 図 18 に示す.

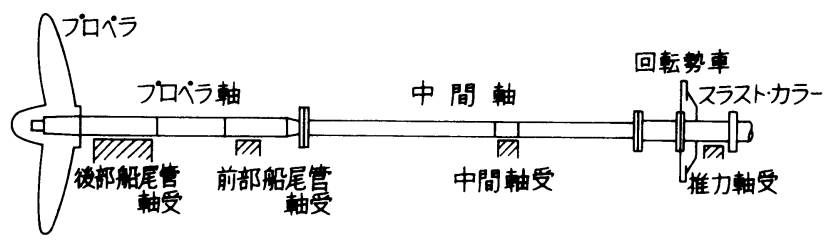

図 17 軸系装置図

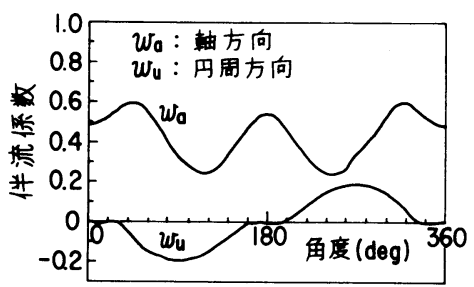

(a) 伴流パターンA

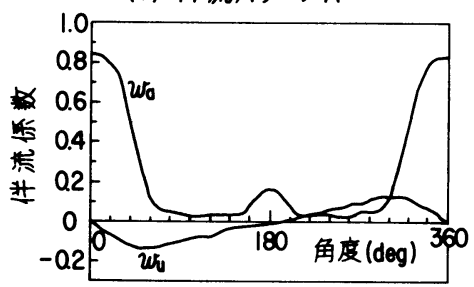

(c) 伴流パターンC

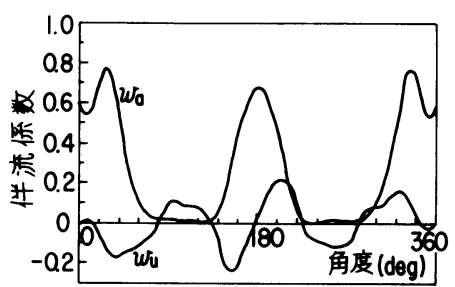

(b) 伴流パターンB

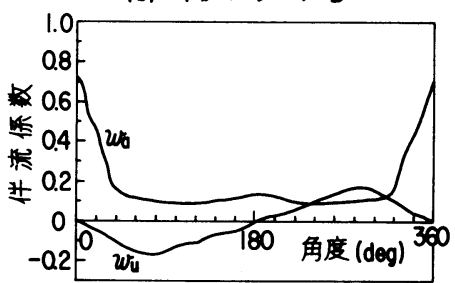

(d) 伴流パターン D
図 18 伴流パターン $(r / R=0.7)$ 
表 2 静的プロペラ・フォース

\begin{tabular}{|c|c|c|c|c|c|c|c|}
\hline $\begin{array}{c}\text { 伴流 } \\
\text { 流-ン }\end{array}$ & $W_{\text {oo }}$ & $W_{10}$ & $W_{\text {Iu }}$ & $\frac{2 F_{Y} R}{Q}$ & $\frac{2 F_{z} R}{Q}$ & $\frac{2 B_{Y}}{T R}$ & $\frac{2 B_{z}}{T R}$ \\
\hline$A$ & 0.433 & 0.090 & 0.163 & 0.114 & 0.141 & 0.156 & 0.158 \\
\hline$B$ & 0.286 & 0.122 & 0.034 & 0.161 & 0.034 & 0.218 & 0.039 \\
\hline$C$ & 0.242 & 0.316 & 0.111 & 0.416 & 0.087 & 0.564 & 0.099 \\
\hline$D$ & 0.181 & 0.142 & 0.147 & 0.195 & 0.121 & 0.257 & 0.130 \\
\hline
\end{tabular}

各伴流パターンから $130 \mathrm{rpm}$ におけるプロペラ・フォ 一スを求めると表 2 となる. 前項で検討したように，プ ロペラ円下部の伴流係数が小さなパターンC の $F_{y}, B_{y} の$ 大きい点が注目される. パターン $\mathrm{B}, \mathrm{C}, \mathrm{D}$ をパターン $\mathrm{A}$ と比較すると， $F_{y} ， B_{y}$ はいずれあ大きく， $F_{z}, B_{z}$ は逆 に小さくなっている. したがって動的アライメント状態 は，パターンAに比べ他のパターンでは，軸が鉛直上方 に持ち上げられる傾向が強く現われると予想される.

各伴流パターンから求められたプロペラ・フォース, ならびに先に求めた軸受特性値を用いて動的アライメン 卜計算を行い, 軸心位置を求めると図 19 から図 22 に示 す結果となる.

伴流パターンAの動的アライメントは他の動的アライ メント状態に比較すると，良好なアライメントになって いる. すなわち十分な油膜厚さが確保され，かつ軸受面 やシール装置のバックアップ・リングなどが, 軸のふれ まわり振動でたたかれるような現象は，発生しないもの と思われる.なお図 19 に示した横振動軌跡は，伴流パ ターン Aから求めたベアリング・フォースを用いて得ら れた軌跡を示している. 本伴流パターンは, 先に示した 対象船に対するパターンであり, 本船は動的アライメン 卜上は特に問題がないと考えられる.

伴流パターン B, Dによる動的アライメントあ，特に問

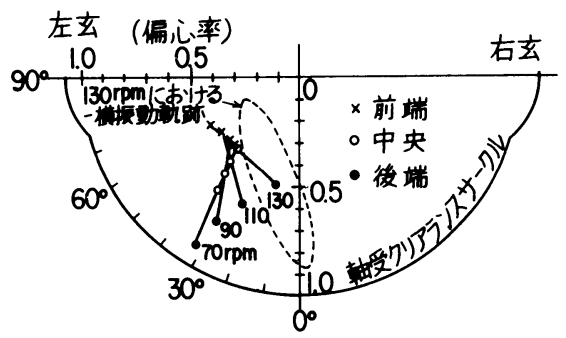

図 19 伴流パターンAによる動的アライメント

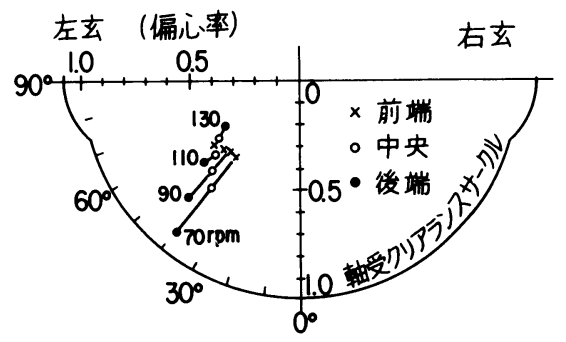

図 20 伴流パターンBによる動的アライメント

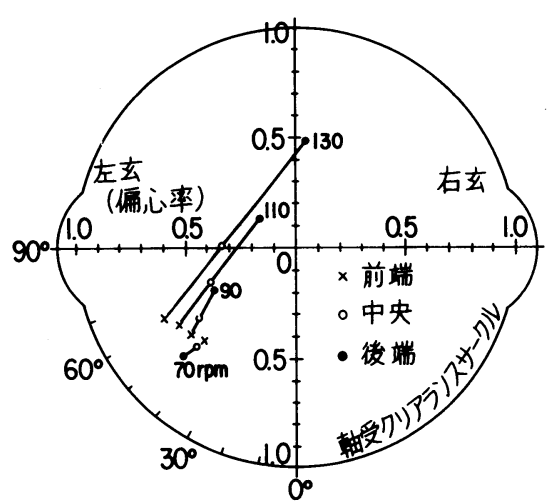

図21 伴流パターンCによる動的アライメント

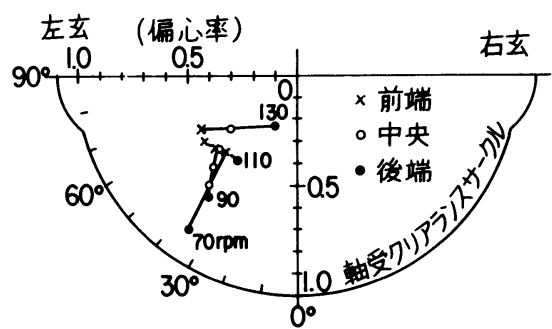

図 22 伴流パターンDによる動的アライメント

題となるような点は見受けられない，しかし，曲げモー メント $B_{y}$ が大きいために，図19に比較すると，130 rpm における軸の持ち上がりがやや大きくなっている.

伴流パターンCによる動的アライメントを図 21 に示 す. 表 2 から明らかなように，伴流パターンCのプロペ ラ・フォースは，曲げモーメント $B_{y}$ が極端に大きいため にてのような結果になっている. 主軸の回転上昇に伴い, プロペラが完全に上方に持上がり, 軸受船尾端の軸心が 軸受上底面近傍に接近している.さらに横振動による変 動分が加わるために，てのような伴流パターンの場合に は, 動的アライメントに注意する必要がある.

第 2 の例として, 動的アライメントの実船計測例につ いて検討する. 対象船は夕ービンを主機とする一軸オイ ル・タンカー10)であり，主要目は以下の上おりである.

載荷重量：400,000LT

定格出力：45,000 PS $\times 80 \mathrm{rpm}\left\{33,098 \mathrm{~kW} \times 80 \mathrm{~min}^{-1}\right\}$ (M.C.O)

プロペラ: 直径 $9.7 \mathrm{~m}$, 重量 $78,650 \mathrm{kgf}\{771.3 \mathrm{kN}\}$ プロペラ軸： $990 \phi \mathrm{mm} \times 9,950 \mathrm{~mm}$ 本船の伴流パターンは図 18 (b) 亿相当する.

喫水変化に伴う二重底の変位を図 23 に示す. 計算値 はSakai-Kanda ${ }^{9)}$ の方法にもとづいて求めたが, 計算 值と計測値はよく一致している．乙の二重底の変位を軸 受支点のオフセット量の変化として考虑し, 軸受荷重を 求めると，表 3 の結果になる. 計測值はジャッキ・アッ プ法で得られた值である. 
軸心軌跡の一例を図 24 に示す. 計測結果から判断す ると, 図 24 に示したようなアライメント状態になるた めには，実船の曲げモーメント $B_{z}$ が，計算值に比べかな り大きいのではないかと推測される. この点に関しては， 実船の伴流分布の推定法上も関係するため, 今後さらに 検討を必要とする.

図 25 に本供試船の偏心率とゾンマフェルト数の関係を 示す. 軸のたわみを無視すると, プロペラ・フォースが 大きくなる高回転領域で，理論曲線から異常な離れ方を 示すが, 軸のたわみを考慮すると，そのような傾向は現

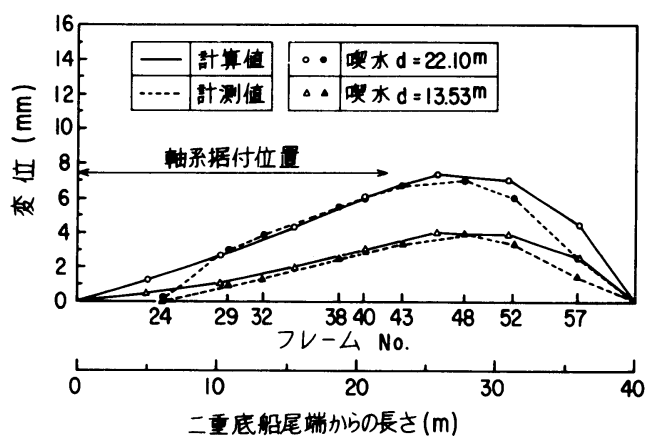

図 23 二重底の変位

表 3 軸受荷重

\begin{tabular}{|c|c|c|c|c|c|c|}
\hline & \multicolumn{5}{|c|}{$\left(x \mid 0^{0} \mathrm{kgt}\{x k N\}\right)$} \\
\hline & & \multicolumn{2}{|c|}{ 船尾管軸受 } & & \multicolumn{2}{|c|}{ 減通西事軸受 } \\
\hline & & 後部 & 前 部 & & 後部 & 前 部 \\
\hline 計画值 & 計算值 & $\begin{array}{r}117.3 \\
\{1,150\}\end{array}$ & $\begin{array}{l}11.2 \\
\{110\}\end{array}$ & $\begin{array}{c}22.1 \\
\{217\}\end{array}$ & $\begin{array}{c}32.8 \\
\{322\}\end{array}$ & $\begin{array}{c}35.8 \\
\{351\}\end{array}$ \\
\hline 呰水 & 計萛値 & $\begin{array}{l}118.1 \\
\{1,158\}\end{array}$ & $\begin{array}{l}10.0 \\
\{98\}\end{array}$ & $\begin{array}{c}22.4 \\
\{220\} \\
\end{array}$ & $\begin{array}{c}31.9 \\
\{3 \mid 3\}\end{array}$ & $\begin{array}{r}36.7 \\
\{360\}\end{array}$ \\
\hline $13.53 \mathrm{~m}$ & 計測值 & & & $\begin{array}{r}30.7 \\
\{301\} \\
\end{array}$ & $\begin{array}{r}27.2 \\
\{267\} \\
\end{array}$ & \\
\hline 舆水 & 計算值 & $\begin{array}{l}117.6 \\
\{1,153\}\end{array}$ & 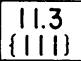 & $\begin{array}{c}20.9 \\
\{205\}\end{array}$ & $\begin{array}{c}34.5 \\
\{338\}\end{array}$ & $\begin{array}{c}34.8 \\
\{341\}\end{array}$ \\
\hline $22.10 \mathrm{~m}$ & 計测值 & & & $\begin{array}{r}29.4 \\
\{288\}\end{array}$ & $\begin{array}{l}35.0 \\
\{343\}\end{array}$ & \\
\hline
\end{tabular}

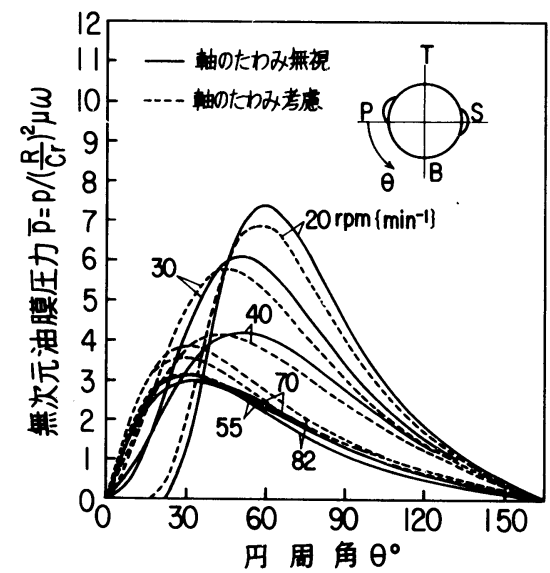

(a) 円周方向圧力分布
われない. したがって，負荷が大きくなる．高回転領域 では軸のたわみを考慮する必要があろう. 図 26 に軸受の 圧力分布を示すが, 軸のたわみを無視すると，低回転領 域では過大評価となり, 高回転領域では過少評価となる.

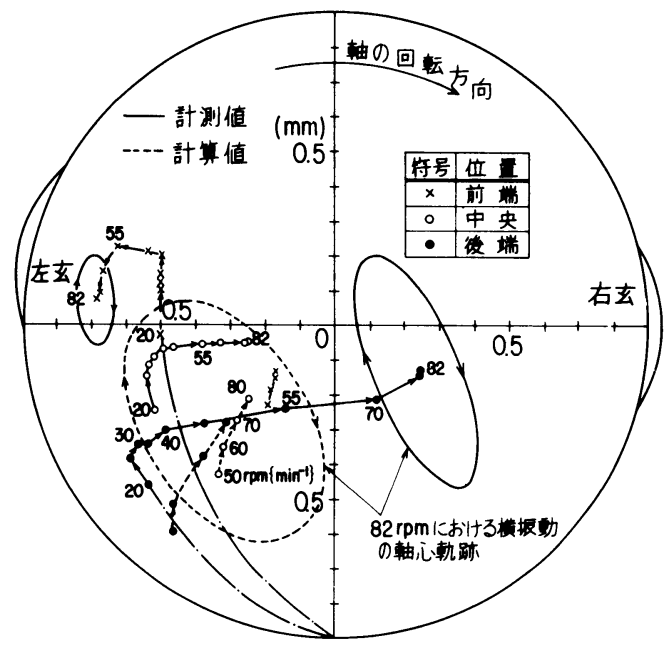

図 24 軸心軌跡の比較

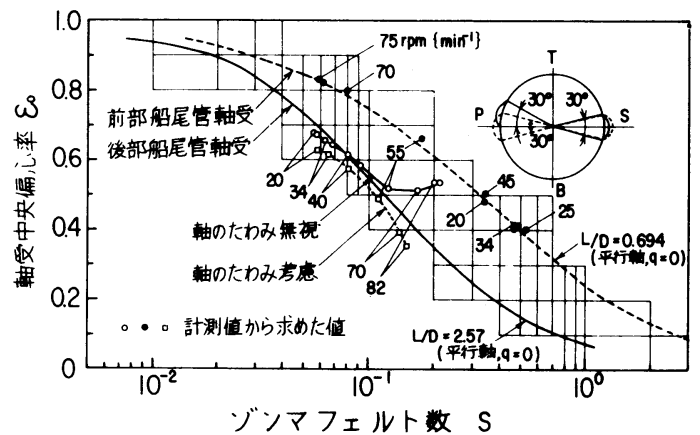

図 25 船尾管軸受油膜特性

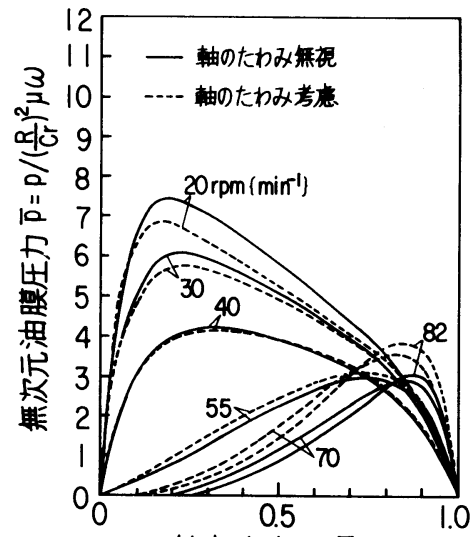

軸方向座椋 $\bar{x}$

(b) 軸方向圧力分布

困 26 最大油膜圧力点の圧力分布(軸心位置は計測値による) 


\section{4. 結言}

プロペラ・フォースならびに軸のたわみを考慮した軸 受特性を，動的アライメント計算に取入れた解析を行 い，若干の検討を行った結果，次のととが明らかになっ た.

（1）伴流分布形状はプロペラ・フォースに，したがっ て動的アライメントに大きな影響をおよぼす，特にプロ ペラ円上部之下部の伴流分布に大きな差がある場合には, プロペラ・フォースが大きくなるため，動的アライメン ト上注意しなりればならない。

（2）実船の軸心軌跡に合うような動的アライメント計 算を行うには，実船の正確な伴流分布の推定が必要不可 欠である.

（3）軸のたわみを無視すると，実際とは異なった軸受 特性が得られるため, 注意しなりればならない。

（4）各種条件の油膜特性をあらかじめ求め，乙れをデ 一タ・バンクとして活用すれば，計算時間の大幅な短縮 が可能である.

現状では，船尾管軸受内の軸の挙動に関する計測例が 少なく，乙のととが動的アライメント計算の確立を困難 にしている. 今後ますます動的アライメント計算の要求 が増えていくと思われるが，そのためには船尾管軸受内 の軸の挙動に関して, 多くの計測とデータの蓄皘が必要 と考える.

\section{文献}

1) O. C. Larsen, Trans I Mar E (C), vol 91, Conference No. 4 (1979), Paper C30.

2) 朝鍋，潤滑，15-5 (昭 45-5)，254.

3）小野・朝鍋・浅井・鷘見，舶機誌， 10-3 (1975)，233

4) 松本・水内 ·斎藤, 関船誌, $184($ 昭 57-3)，29.

5）見，舶機誌，13-9 (昭 53-9)，628.

6) Vogelpohl, G, VDI-Forschungsheft (1937), 386.

7) O. Pinkus, W. Shapiro, MARAD Report No. MA-RD920-79009, (1978-11).

8）安濃田・葉山，舶機会昭和 50 年秋季講演会前刷.

9) H. Sakai, Y. Kanda, Journal of the Faculty of Engineering, The University of Tokyo (B), Vol. XXXIV, No. 4 (1978), 589.

10）斎藤・水内・松本ほ加，舶機誌，13-12（昭 53-12）, 903.

\section{〔質 疑 応 答〕}

質問者 (財) 日本海事協会 久米 宏

【買间〕伴流を考虑することは，プロペラ動的外力を 考虑することであり，てれはプロペラの翼数によって， 様相が大きく異なる．横振動の計算に当って，乙の変動 外力を考虑した上で軸系中心線の変動計算ができるよう に，伴流分布と翼数の両者を考慮に入れた実機に適用で きる計算手法の解明に更に研究を進めていただきたい.
【回答〕本報で取扱った軸系アライメント計算は，大 別するとふたつの部分に分けられる.

第 1 は，定常運転状態における，軸心の静的釣合位置 を，軸受油膜特性と静的プロペラ・フォースを用いて求 める計算である. この計算で用いるプロペラ・フォース は一定の大きさで軸を押したり，曲げたりする力であり， この力は 1 次の伴流成分に関係し，プロペラ翼数には関 係しない。

第 2 は，定常運転状態に重畳される，微小振幅を仮定 した横振動計算である，軸の横振動に寄与する力，すな わちべアリング・フォースは，当然のととながら伴流分 布とプロペラ翼数に関係する.

たとえば，困19に実線で示した軸心位置は，静的プ ロペラ・フォースより求めた結果であり，破線で示した 翼数次振動の軸心軌跡は, 翼数を考慮して求めた動的プ ロペラ・フォースを用いて求めた結果である.

質問者 三井造船 (株)玉野研究所 三井純一

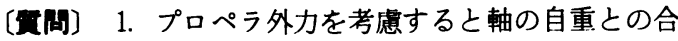
カベクトルの方向が変動する. 給油溝がある場合, 特に 給油溝角度が大きい場合は油膜特性も異なることにな る.

ての点に関してはどのように扱っておられるのか.

2. 油膜特性に関するデータ補間の方法を詳しく御教 示いただきたい。

[回签] 1. ご指摘のとおり，プロペラ外力が作用する と, 軸系と自重と外力による合力ベクトルの方向 (本文 困 3 の角度 $\delta$ ) が変わり, 軸受の負荷容量が変化する. この角度変化は外力が作用しない場合に比べ, M.C.R.で 約 $3^{\circ} \sim 5^{\circ}$ 程度であり，負荷容量の変化は偏心率 0.8 に対 し 2〜3\%程度の変化之なる. あちろん条件によりこの 值む変化するが 一般に偏心率が大きいほど変化す大き い.

軸受油膜の静特性を求める段階では，乙の角度 $\delta$ をパ ラメータとして数種の計算を行い, データ・バンクとし て格納する．しかし，静的プロペラ・フォースが軸受の 静荷重に比へて小さい場合には，1次近似的には無視し てよいと考える.

2. 補間に至る過程は以下のとおりである

(1) あらかじめ, ミスアライメントを定義する各種定 数（文献 4) 参照)について，すなわち $q$ (軸の勾配)， $\alpha$ (軸心と軸心中央を通る直径とのなす角度)，入(軸のた わみ), $\chi$ (たわみの方向), $\delta$ (荷重べクトルの方向)の 各種パラメータについて，偏心率一負荷容量 $\left(\varepsilon_{0}-\bar{W}(q\right.$, $\alpha, \lambda, \chi, \delta))$, 偏角一負荷容量 $\left(\varphi_{0}-\bar{W}(q, \alpha, \lambda, \chi, \delta)\right)$ の関係を求め, データ・バンクに格納する.

(2) アライメント計算を実行し $\bar{W}, q, \alpha, \lambda, \chi, \delta, \varepsilon_{0}^{\prime}$ (軸受中央偏心率)を求める. ここで得られた $\alpha, \lambda, \chi, \delta$ に最む近い值 $\alpha_{1}, \lambda_{1}, \chi_{1}, \delta_{1}$ を指定する。

(3) アライメント計算で得られた $q$ に最も近いデータ ・バンク内の格納值 $q_{1}, q_{2}\left(q_{1} \leq q \leq q_{2}\right)$ について, $\bar{W}\left(q_{1}\right.$, 
$\left.\alpha_{1}, \lambda_{1}, \chi_{1}, \delta_{1}\right)$ に相当する $\varepsilon_{1}^{\prime}$ ならびに $\varphi_{1}^{\prime}$ を求める. 次いで $\bar{W}\left(q_{2}, \alpha_{1}, \lambda_{1}, \chi_{1}, \delta_{1}\right)$ に相当する $\varepsilon_{2}^{\prime}$ ならびに $\varphi_{2}^{\prime}$ を求める.

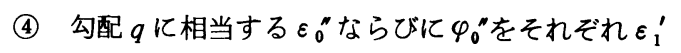

と $\varepsilon_{2}^{\prime}$ ならびに $\varphi_{1}^{\prime}$ と $\varphi_{2}^{\prime}$ から補間により求める.

(5) アライメント計算で得られた $\varepsilon_{0}^{\prime}$ と油膜特性から 得られた $\varepsilon_{0}$ ”を比較し, 許容值内にあるかどうかを確認 する. 